\title{
Myelodysplastic Syndrome 2 Translocation-Associated Protein
}

National Cancer Institute

\section{Source}

National Cancer Institute. Myelodysplastic Syndrome 2 Translocation-Associated

Protein. NCI Thesaurus. Code C97617.

Myelodysplastic syndrome 2 translocation-associated protein (140 aa, $\sim 15 \mathrm{kDa}$ ) is encoded by the human MDS2 gene. This protein plays a role in myelodysplastic syndrome. 